\title{
Analysis of educational leadership at rural early-childhood and primary schools: a case study in Teruel (Aragon, Spain) ${ }^{1}$
}

\author{
Juan Lorenzo Lacruz (jlorenzo@unizar.es)² \\ Virginia Domingo Cebrián \\ Alberto Nolasco Hernández \\ Pilar Abós Olivares
}

\section{Abstract}

Rural schools are a distinctive feature in the autonomous community of Aragon, as state-run rural schools are the main cultural institution in small towns. This research was conducted in four grouped rural schools (hereafter referred to by their Spanish acronym, CRAs) in the province of Teruel in 2017. Our objectives included analysing the views of management team members and teachers on educational leadership with a special emphasis on the rural school's differentiating elements. Four CRAs were chosen in the province of Teruel. Three teachers and six members of management teams participated and the study data were collected using a qualitative interview. The content analysis of the interview was conducted using the NVivo program and was organised into two fundamental areas: views of educational leadership and the skills this leadership includes. The general perception of management teams and teachers is positive; they value the effort put into performing the work and understand that both management and CRAs are complex. They also appreciate the management teams' organisation of training and its contents. This analysis suggests a set

\footnotetext{
1 Juan Lorenzo Lacruz, Virginia Domingo Cebrián, Alberto Nolasco Hernández \& Pilar Abós Olivares (2019): Analysis of educational leadership at rural early-childhood and primary schools: a case study in Teruel (Aragon, Spain), International Journal of Leadership in Education, DOI: 10.1080/13603124.2019.1657590

Full text avaible on:

https://www.tandfonline.com/doi/abs/10.1080/13603124.2019.1657590?journalCode=tedl20

${ }^{2}$ Departament of Educational Sciences, University of Zaragoza (Spain)
} 
of conditions that provides a qualitative insight into management possibilities and limitations in the CRA model.

Keywords: rural school, grouped rural school, educational leadership, Spain.

\section{Introduction}

This article stems from the research project of the Antonio Gargallo Foundation of Teruel entitled 'Grouped Rural Schools (CRAs) in the province of Teruel. Analysis of the organisational model, leadership and teacher training', conducted by researchers in the EDI (Education and Diversity) research group formed by lecturers from the Faculty of Social and Human Sciences of Teruel, the Faculty of Education of Zaragoza and the Faculties of Human Sciences and Education of Huesca, which all belong to the University of Zaragoza. The research project members have extensive experience in rural schools, teacher training environments and school leadership.

The research took place in 2017 in four CRAs offering early-childhood and primary education in the province of Teruel (Autonomous Community of Aragon, Spain). The study sample comprises nine education professionals; six are members of management teams and the other three are teachers.

Aragonese rural schools are a reality within the school system, with specific forms of organisation, a special spatial and personnel structure and distinctive educational and curricular models. They are essential in the autonomous community of Aragon because, besides an imbalanced distribution of population and resources compared with the autonomous community capital, Saragossa, and the provincial and district capitals, state-run rural schools are the main cultural institution in small towns in Aragon. Keeping rural schools open is directly linked to the survival of these towns and also associated with rural exodus processes, new migration flows, changes in the 
production system with new economic sectors, and the existence of infrastructures and comprehensive development plans that ensure the future of these towns and their schools.

Based on the aforementioned ideas, the main research issue is addressed to deepen in the knowledge about the perception of the educational leadership in the specific context of the Aragonese rural school and verify the skills needed for a sustainable educational quality. Therefore, the main objectives the research team focused on were:

1. Identifyingthe views of CRA management teams and teachers on educational leadership.

2. Analysing the skills the management teams and teachers consider essential for quality educational leadership.

The key to meeting any educational organisation's requirements and needs is to identify and understand them. Therefore, this article explores rural schools' needs from the perspective of their educational stakeholders. The main point is to research the overriding challenges and possibilities of rural schools for the development of educational leadership seeking improved quality.

\section{Theoretical substantiation}

\section{Rural schools: a theoretical approach}

A theoretical approach to the concept of rural schools cannot overlook the initial idea that education cannot be understood from an economic stance only and that staterun schools, according to Morales, 'reach the places where a private company's economic rationality would never go' (2007: 140); and rural schools are, always, staterun schools. For rural areas, the alternative is not between a state-run school and a private school, but between a state-run school and nothing (Bernat, 2009). 
Based on this fact, we should remember that the term 'rural school', as Barthes and Alpe (2017) highlight, is a complex and polysemic term that is controversial in both political and educational circles; it generally refers to schools located in areas far from the main urban centres and from the institutions responsible for political and economic decision-making (Gauthier and Luginbühl, 2012). Rural school conditions are also the cause of some dysfunctions that are not strictly educational, since educational policies are primarily based on the urban school model and the specifics of rural schools, or the problems they face, are only assessed in reference to the urban model. This is the reason why, as Barthes and Alpe point out, the stakeholders themselves-teachers, families and the local community-on rural schools ask the main questions concerning fundamental issues such as equal opportunities, teacher training and citizen education. Schools form part of an institutional system in a specific territory (Prats, 2004) and rural schools are located in spaces linked to the land and defined as a result of it; spaces that acquire their own identity (Bustos, 2009). This leads to questions that can encourage society to demand coherent social policies that defend the principles of equal results and participation (Bernat, 2009).

As Canário says (2008), the future of rural schools is not just an internal issue of educational systems, but related to the future of rural areas and, therefore, to the overall structure of our society. Consequently, although rural schools have been studied in the research community, there is no well-established and common definition, implying that studies have targeted different aspects (geographical, sociological, educational and so on). For all of the above, the framework of our study is educational, focusing on organisational and teaching aspects.

\section{Rural schools in Spain}

Rural schools in Spain are defined by two basic ideas: diversity and invisibility (García, Pozuelos and Álvarez, 2017). The former is obvious and the subject of most research, whether focused on sociological aspects such as 
demographics, culture or economics, or educational aspects, since rural school pupils come from a variety of social and personal backgrounds and children of different ages share the same classroom; rural schools and diversity go hand-inhand. The latter, invisibility, is real because fewer people live in rural areas and they are often isolated; as a result, they are not as important in decision-making despite being a differentiated reality in Spain's decentralised educational system in many autonomous communities, including Aragon. In this autonomous community, rural schools are a mark of identity and, as a result, as Boix (2014) says, they should be addressed as an active social issue so that diversity becomes the great strength that makes them visible.

The main organisational structure in Spanish rural schools, even though they adopt different names (State-run Rural Schools, Rural School Areas, Grouped Rural Schools, and so on), is an unusual arrangement of space and personnel and uses an educational and curricular model with specific characteristics:

Grouped rural schools (CRAs) are a combination of small schools in the same district forming a single school unit. In each school there is a teacher-tutor with a small number of students aged between three and 12 (second cycle of early-childhood education and first, second and third cycles of primary education) who teaches them basic subjects and areas; specialised subjects-English, physical education and music-are taught by peripatetic teachers attached to a grouped rural school (CRA) in a nearby municipality with a higher enrolment rate (Gómez, 2007:87).

A grouped rural school is a school where early-childhood education and primary education are taught in a rural setting. It has different names depending on its geographical location [...] It is a single unit with classrooms spread out in different localities at varying distances from each other. Localities are generally grouped together when their student numbers do not make it possible to have one-year group per educational level [...] The locality with the most classrooms will be the 
head of the CRA where the administrative work and management are centralised (Tapia and Castro, 2011: 416-417).

In Aragon, there are different resources, developed by the Aragon Gouvernement and the Aragonese Institute of Statistics (http://www.aragon.es/iaest), that help to increase the knowledge about how a CRA works. Some virtual resources allow an understanding, in an statistical and schematic way, what is the relationship and the links between the different schools that are encompassed in a CRA, for example the report "The education in the CRA for Aragón: analyses of actual data and approach" (available online in: https://opendata.aragon.es/servicios/cras/static/informe_cra_aragon.pdf). In the figure below we can see an interactive map provided for the virtual Open Data platform depending of Aragon Government. This virtual space provides several data for each CRA of Aragon and gives historical information about the numbers of school establishment and its demography, the evolution of registered students and their distribution in the different educational stages.

Figure 1. Example of map and data of the CRA in Aragon (Source: IAEST. Retrieved from: https://opendata.aragon.es/servicios/cras//) 

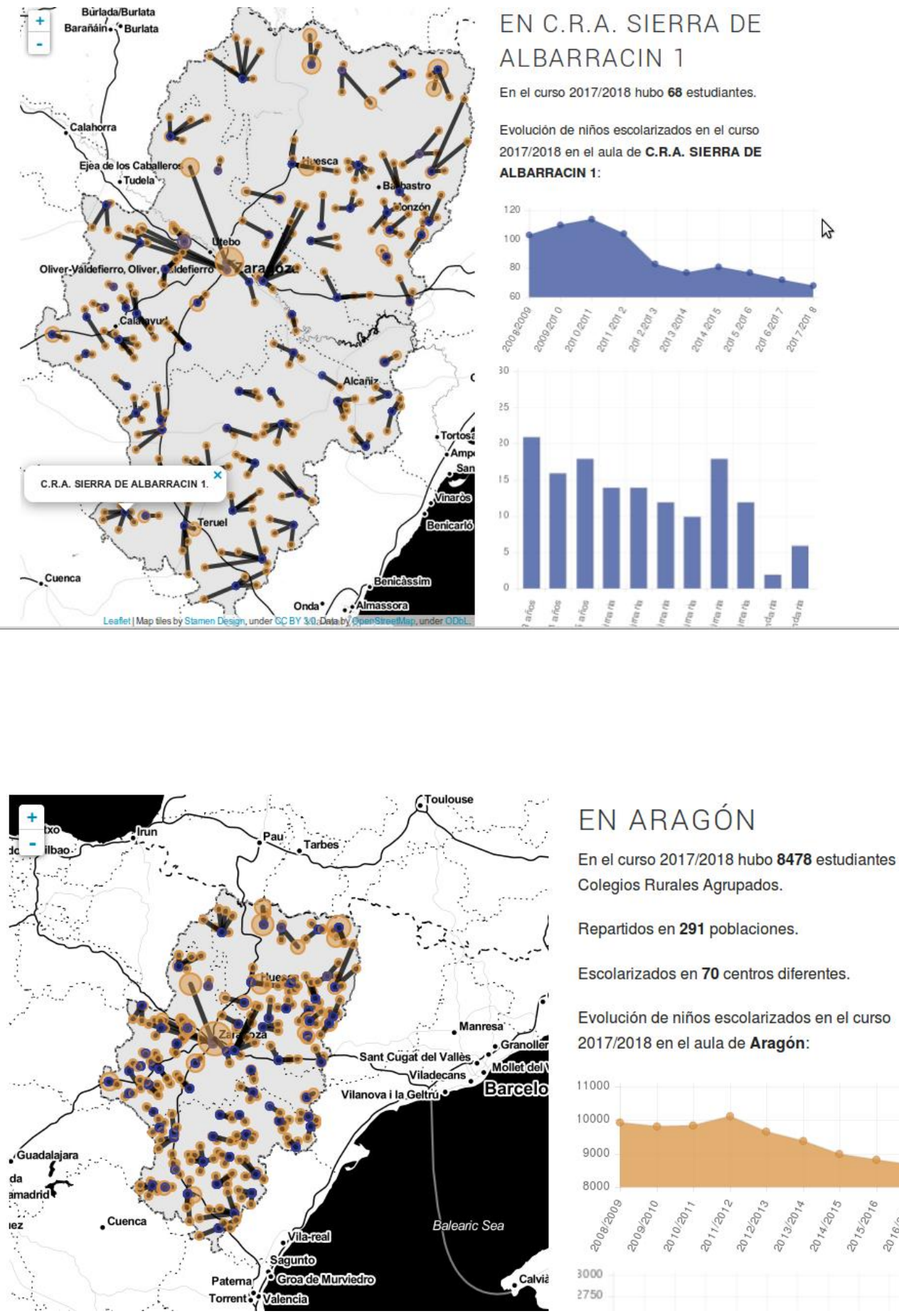

\section{EN ARAGÓN}

En el curso 2017/2018 hubo 8478 estudiantes en Colegios Rurales Agrupados.

Repartidos en 291 poblaciones.

Escolarizados en 70 centros diferentes.

Evolución de niños escolarizados en el curso 2017/2018 en el aula de Aragón:

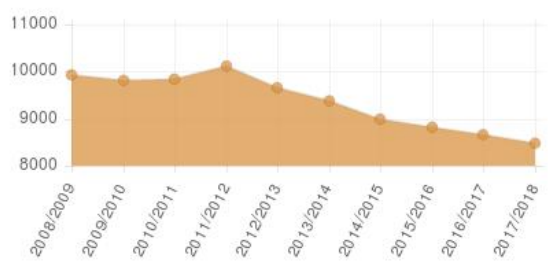

Nevertheless, this model still has problems and limitations. Rural schools are still not appropriately differentiated in legislation for either curricular or organisational aspects and 'suffer' the effects of overarching uniformity. 
Morales conducted an interesting analysis on the consequences of the global economic process and its impact on the rural environment to start a discussion on the pre-eminence of economic criteria over social aspects through key concepts of neoliberal 'jargon', such as efficiency, streamlining and reorganisation. Based on the premises of social ecology, this author believes that the existence of social and educational services in rural areas cannot be conditioned by how much it costs to run them and, instead, it should depend on the inhabitants' quality of life. She says that 'in Spain, the local perspective has not been considered in educational planning' (2007: 142). Morales (ib) highlights that keeping state-run rural schools open primarily on the basis of their profit margins risks the long-term survival of the towns where these schools are located.

In a recent study, Morales (2017) shows that most teachers, parents and headteachers interviewed thought rural schools in Spain were not receiving the appropriate attention according to their characteristics and their qualitative and quantitative importance, as educational laws since the second half of the nineteenth century have not considered inequalities arising from place of residence. She states that one of the main problems facing rural schools, according to the interviewed subjects, was the lack of support for management teams. Nevertheless, they also considered that classroom diversity encouraged more active, flexible and innovative methodological approaches.

In an attempt to turn minuses into pluses, rural schools should be the first to realise that their differentiating characteristics can become possibilities without having to adopt certain urban-centric models (Boix, 2003; Corchón, Raso and Hinojo, 2013), although political, economic, social and educational measures are required (Gallardo, 2011; Tapia and Castro, 2014). These measures should include appropriate leadership in line with the participatory equality and compensating quality of education to strengthen a democratic culture that considers the environment's characteristics.

All these factors further underscores why studying educational leadership in rural schools is important, since it is a fundamental skill, especially as rural schools are 
often separated by some considerable distance. Therefore, good CRA coordination and appropriate educational leadership are essential in this type of school. In the next section we will review the status of educational leadership in rural schools.

\section{Educational leadership in rural schools}

School leadership is crucial for improving education considering that headteachers have the final say in preventing or promoting measures to support social cohesion and teaching staff's teamwork (Murillo, 2006). Participatory, democratic and transformational leadership exerts a positive influence on improving schools and on creating an inclusive culture (León, Crisol and Moreno, 2018). Consequently, quality leadership requires knowing how to promote a democratic culture linking the school's environment to educational action; this idea is especially important in rural schools.

Hopkins (2001) states that educational transformational leadership is vital for schools to be successful in challenging contexts such as rural areas. However, other research shows that the leaders of this school type usually have an autocratic style, especially in the first phases of improvement processes, even though this style is often not the most appropriate to sustain said processes (Chapman, 2005; Muijs, 2007). Other studies have stressed the importance of distributed leadership as the best way to start and, above all, sustain change in heterogeneous schools (Harris and Chapman, 2002), especially considering that this leadership type is contextualised and committed to difference (Gunter, 2006) and critical of standardised forms of schooling.

Consequently, it seems we can confirm that headteachers adopt forms of leadership that are intimately related to the school's context and requirements within the framework ofcontingency theory, although recognising a predominant management style in these schools would be impossible. Nevertheless, we can state that research does not highlight one leadership style in particular as the most effective, but it does suggest that distributed and participatory leadership could be (Harris and Muijs, 2002). In this sense, Murillo says that: 
Distributed leadership is a new conceptual framework for analysing and addressing school leadership. It is far more than a simple reorganisation of tasks; it means a change in culture, a culture that involves the commitment and involvement of all the members of the school community in the running, operation and management of the school (2006: 19).

Maureira et al. posit that 'distributed leadership can be a more assertive way of influencing scenarios in a complex society rich in information and knowledge' (2015: 694). Bolívar gives us a highly interesting stance on change in leadership models from classic vertical management to a shared, distributed model. Bolivarstates that 'instead of controlling, ordering and predicting, in a post-bureaucratic era, we should involve, motivate and encourage people to bring out the best in themselves in the assigned tasks' (2011: 255). Rural schools could adapt to contexts that encourage this type of reconceptualised leadership since they are 'schools experienced as a community; teachers share leadership and decision-making, they become involved in action, they participate in collaborative work and they accept responsibility for the results of their work' (2011: 269).

To explore this new leadership model in more depth through research in Englishspeaking countries and Latin America (Álvarez, 2010), Bolívar tried to detect management skills that characterise this leadership type grouped into four areas: personal qualities, interpersonal skills, management ability and technical management skills.

Similarly, it is essential to discover the skills managers should acquire and use to be formal or informal leaders in contexts as complex and delicate as educational organisations and schools in rural settings, located in diferentcontexts due to their geographical, socioeconomic and cultural characteristics. Knowledge and adapting to the context should be one of the guidelines for selecting a leadership style whose aim is seeking development opportunities and building and maintaining an effective learning atmosphere and a positive school environment (Mullins et al., 2009). 


\section{Materials and methods}

The research took place in the province of Teruel (Aragon, Spain) in 2017. Based on the above-mentioned objectives, it focuses, firstly, on the views of management teams and teachers in grouped rural schools on educational leadership according to three variables or categories (Ritacco and Amores, 2017)-constituent elements, resistance and limitations, and requirements and possibilities in the context of rural schools-(Objective 1); and, secondly, on the views of the skills they consider essential for quality educational leadership (Objective 2), which, according to the review by Ritacco and Amores (2017), would include 'directions, requirements and shared commitments', 'professional development and training' and 'collaborative organisation and institutional improvement'.

Based on these initial outlines, four CRAs were chosen ${ }^{3}$ in the province of Teruel. These CRAs were chosen for several demographic reasons. Since we wanted a sample that represented different regions in the province of Teruel, we selected four CRAs belonging to different training and innovation units (UFIs, for its acronym in Spanish). They are all small continuing education centres depending on a central headquarters managed from Teruel and they are responsible for training in rural environments - each in their own territory.

We tried to ensure all four were near the city of Teruel to facilitate access. Each CRA was asked for one member of the management team and one teacher to participate, although, as can be seen from the data in table 1 , these expectations were not met. They were contacted by telephone and/or email to inform them about the project and ask about their availability to participate. The characteristics of the CRAs and the participants at each one were:

From now on, the schools will be described as school 1, school 2, school 3 and school 4. 
Table 1. Centres

\begin{tabular}{|l|l|l|l|l|}
\hline Centre & №. Localities & №. Classrooms & Teachers & Students \\
\hline 1 & 6 & 9 & 15 & 81 \\
\hline 2 & 2 & 3 & 5 & 17 \\
\hline 3 & 7 & 14 & 20 & 98 \\
\hline 4 & 7 & 10 & 18 & 68 \\
\hline
\end{tabular}

Table 2. Participants and professional career

\begin{tabular}{|c|c|c|c|c|c|c|}
\hline School & $\begin{array}{l}\text { Management } \\
\text { team }\end{array}$ & $\begin{array}{l}\text { Years of } \\
\text { teaching }\end{array}$ & $\begin{array}{l}\text { Teaching } \\
\text { in CRA }\end{array}$ & Teacher & $\begin{array}{l}\text { Years of } \\
\text { teaching }\end{array}$ & $\begin{array}{l}\text { Teaching } \\
\text { in CRA }\end{array}$ \\
\hline 1 & $\begin{array}{l}\text { Head of } \\
\text { studies (HS1) }\end{array}$ & $>15$ & $>5$ & $\begin{array}{l}\text { Tutor } \\
\text { (T1) }\end{array}$ & $>20$ & $>5$ \\
\hline \multirow[t]{2}{*}{2} & $\begin{array}{l}\text { Headteacher } \\
(\mathrm{HT} 2)\end{array}$ & $>10$ & $>10$ & \multirow{2}{*}{$\begin{array}{l}\text { Tutor } \\
\text { (T2) }\end{array}$} & \multirow[t]{2}{*}{$<5$} & \multirow[t]{2}{*}{$<5$} \\
\hline & $\begin{array}{l}\text { Substitute } \\
\text { headteacher } \\
\text { (SubHT2) }\end{array}$ & $<5$ & $<3$ & & & \\
\hline \multirow[t]{2}{*}{3} & $\begin{array}{l}\text { Headteacher } \\
\text { (HT3) }\end{array}$ & $>20$ & $>15$ & \multirow{3}{*}{$\begin{array}{l}\text { Peripatetic } 4 \\
\text { (T3) }\end{array}$} & \multirow[t]{3}{*}{$>5$} & \multirow[t]{3}{*}{$<5$} \\
\hline & $\begin{array}{l}\text { Head of } \\
\text { studies (HS3) }\end{array}$ & $>10$ & $>5$ & & & \\
\hline 4 & $\begin{array}{l}\text { Head of } \\
\text { studies (HS4) }\end{array}$ & $>10$ & $>10$ & & & \\
\hline Total & 6 & & & 3 & & \\
\hline
\end{tabular}

$4 \quad$ The peripatetic teacher gives specialised classes (physical education, music or foreign language) at different locations in a grouped rural school. 
Considering that the essential content was the study of educational leadership, to obtain information we adapted the interview instrument by Ritacco and Amores (2017) to the characteristics of the CRAs in Aragon, as it was originally used in a nonrural setting. In this interview, the subjects were asked about the skills that the scientific literature included in educational leadership, understood as 'a group of people who learn and work together in a professional learning community with a shared purpose' (Bolívar, 2012: 257).

The interviews were conducted by the research team members in January and March 2017-in the Faculty of Social and Human Sciences or in the schools themselvesand audio recorded with the participants' prior consent. The content was analysed using the NVivo program to reduce and categorise the data. A coding nomenclature was established first (Wertz et al., 2011) to organise the units identified in the interviews into two categories based on similarities and associations with the research themes: firstly, those referring to the view of educational leadership (category 1 ) at the schools and, secondly, the presence/absence of skills (category 2) considered to form the elements of this leadership. Therefore, the first coding using the NVivo program was deductive. Nevertheless, the first coding process led to others, so we can talk of a mixed model. A second analysis was performed to increase the level of specification in each of them. This resulted in identifyin the subcategories and their corresponding indicators,

\section{Results}

As mentioned in the section above, the interview content was organised into two main areas: view of educational leadership and skills this leadership includes. Tables 2 and 3 show the basic data of this analysis and table 4 the data on 'other categories' arising from the interview content.

Table 3. Content analysis: Educational leadership category 


\begin{tabular}{|l|l|l|}
\hline \multicolumn{3}{|c|}{ Subcategories } \\
\hline \multicolumn{1}{|c|}{$\begin{array}{c}\text { View of educational } \\
\text { leadership }\end{array}$} & $\begin{array}{c}\text { Requirements and } \\
\text { possibilities for educational } \\
\text { leadership }\end{array}$ & $\begin{array}{c}\text { Resistance and limitations for } \\
\text { educational leadership }\end{array}$ \\
\hline \multicolumn{2}{|c|}{ Indicators } \\
\hline Knowledge & Specific training & High teacher turnover \\
\hline Teamwork & Inspection support & Appointed management teams \\
\hline Example & Appreciation of personnel & Lack of time for MT joint work \\
\hline Experience & & More effort/bureaucracy \\
\hline
\end{tabular}

\section{Category 1 Educational Leadership}

\section{Subcategory 1 View}

The views management teams and teachers have of educational leadership, , is that it is a requirement of a good headteacher and involves, as Spillane and Camburn (2006) and Day, Gu and Sammons (2016) have pointed out, certain personal characteristics. The study participants identified the following characteristics of appropriate educational leadership:

'... being quite empathetic, putting oneself in someone else's shoes, communication skills ... ability to encourage.' (HT2); '... who always asks questions.' (HS3); '... ability to listen.' (T3); '... a person's character is very important ... a character that knows how to explain things really well.' (HS3); '... has to be close to the teachers.' (HS4); '...wasn't close to the people at all ... stayed in the office.' (HS3)

and abilities and skills that can and should be acquired through training and experience: 
'I've understood this role as my position, my work as headteacher, progressed.' (HT2); '... knowledge of rules and management.' (T3); 'has many years of experience.' (HS3); '... ability to collaborate.' (HS3); '... to create a collaborative environment ...' (HS1)

One of the most significant aspects about this point, highlighted in all the interviews, is the importance of the person holding the position of headteacher setting an example in the classroom and in the school and getting involved in what they do:

'... now I see that you always have to set the first example ... draw the lines, justify them and say how things are to be done ...'. (HS4); 'They should set an example in their own classroom.' (T1); 'They should get involved.' (T1)

\section{Subcategory 2 Requirements and possibilities}

This subcategory is for the personal and contextual conditions considered necessary for educational leadership, since they are quoted as the conditions currently in schools that would make educational leadership difficult if they did not exist. One of the most emphasised conditions is that the headteacher should appreciate their staff's diversity, encourage their contributions and promote active participation in decision-making:

'... everyone has some potential, so trying to find that potential so it can be developed ... Perhaps there are teachers who have far better developed skills.' (HT2); 'There are staff with tremendous skills, but you have to value them and bring them to the fore ... learn a lot from people who come with knowledge that I don't have.' (HT3); 'it depends a lot on your personal skills.'

'... it's interesting that a peripatetic teacher is in the management team ...'. (HS4) 
The differentiating characteristics of a rural school (size, knowledge of the community, importance of its existence, and so on) are also considered elements that make better educational leadership possible:

'... there is far more involvement than at any school in Teruel ... work is different in a rural school.' (HT2); '... relationships are completely different ... it's easier in the towns ... the school's value is very important, as is improving that value.' (HS3); 'Here you get to know the family, colleagues.'

Considering the physical features of a CRA, with the distance between classrooms as one of the most characteristic, most of the interviewees value ICT highly as a tool that makes coordination possible and for this coordination to be real:

'... they are uploaded to Google Drive ... we often just send an email.' (HS3)

\section{Subcategory 3 Resistance and limitations}

At the four schools, both the management teams and the teachers mentioned a series of specific limitations of the CRAs that prevent real educational leadership. They very specifically include high teacher turnover:

'All the teachers changed this year.' (HT2); '... you really have to take into account the staff you have this year.' (HS1); '... there's usually a high staff turnover in a rural environment ... staff changing jobs is difficult for headteachers.' (T1); 'Half of the teachers is new from one year to the next ... places where the teacher spends one year ... it's exhausting.' (HT3); '... in the CRA, $50 \%$ changes every year. That just grinds us to a halt.' (HS1) 
Lack of time for joint work combined with the distance between localities and excessive bureaucracy are also elements preventing appropriate leadership:

'Time to think and share ... Too much bureaucracy.' (HS4); '... it's actually very complicated ... there's not much time to coordinate ... lack of time is obvious.' (HS1); '.. the fact that we're not all in the same place can be a minor handicap.'

(HS3); 'We have very little time to see each other every week.' (T1); '... sometimes we don't have enough time to coordinate.' (T3)

Another of the highlighted difficulties is that the headteachers of the CRAs have often not been elected, as they are holding the position out of obligation:

'... many teams have been appointed and not elected.' (HS4); 'The headteacher is often in this role because no one else wanted to be headteacher.' (T1)

\section{Category 2 Educational Leadership Skills}

Table 4. Content analysis: Category: educational leadership skills

\begin{tabular}{|c|c|c|c|}
\hline \multicolumn{4}{|c|}{ Subcategories } \\
\hline $\begin{array}{c}\text { Shared management, } \\
\text { requirements and } \\
\text { commitments }\end{array}$ & $\begin{array}{c}\text { Professional } \\
\text { development and } \\
\text { training }\end{array}$ & $\begin{array}{c}\text { Collaborative } \\
\text { organisation }\end{array}$ & $\begin{array}{c}\text { Institutional } \\
\text { improvement }\end{array}$ \\
\hline \multicolumn{2}{|c|}{ Indicators } \\
\hline $\begin{array}{c}\text { Example and personal } \\
\text { involvement }\end{array}$ & Teams & School size & $\begin{array}{c}\text { Adaptation to } \\
\text { requirements }\end{array}$ \\
\hline
\end{tabular}




\begin{tabular}{|c|c|c|c|}
\hline Belonging & Information & Communication & $\begin{array}{l}\text { Involvement with } \\
\text { education } \\
\text { community }\end{array}$ \\
\hline Continuity over time & $\begin{array}{c}\text { Relationship to } \\
\text { practice }\end{array}$ & Belonging & Joint proposals \\
\hline Organisational area & Belonging (school) & Sharing & Educational area \\
\hline Educational area & $\begin{array}{l}\text { COFO (training } \\
\text { coordinator) }\end{array}$ & $\begin{array}{l}\text { Joint education } \\
\text { plans }\end{array}$ & \\
\hline $\begin{array}{c}\text { Learning and } \\
\text { socialisation as key } \\
\text { points }\end{array}$ & Involvement & Opening & \\
\hline
\end{tabular}

\section{Subcategory 1 Shared management, requirements and commitments}

On analysing the interviews of the management teams and teachers, we can see that some common management lines are set in most CRAs based on a series of long-, medium- and short-term objectives. In the latter case, the end of year report is a basic element for the following year so certain subjects can be prioritised and kept despite many teachers leaving: common courses of action are essential.

'At the first CRA meeting in September, when we get together for the first time, there are some teachers who have been there for several years and other teachers who are new and we talk about the courses of action for this academic year.' (HS3); 'Yes, because that was what they presented to us on the first day. At other schools, I've never known what the objectives for the year were.' (SubHT2) 'All the teachers changed this year, so I told them how some things work at the beginning of the year. ... There has to be a common framework ... We can't change everything constantly.' (HT2); 'If you outline how we have to work and everyone takes on board what they have to do ... 
we work together.' (HT3); 'We try to follow the same course of action.' (T3); 'We have to follow the same course of action ... we're in a system and that system has a course of action.' (HS3)

The specificity of the CRA is one of the basic elements in establishing common courses of action and requirements, considering high teaching staff turnover:

'... we begin to emphasise that we are a CRA and all the localities should follow the same course of action.' (HT2)

And there are essentially two objectives. Firstly, coexistence at the schools: 'The first objective would be coexistence and a good atmosphere at my school. That's a priority for me ... Encouraging coexistence with your pupils and with the teachers.' (HT3); 'I want it to be a lively, dynamic school.' (HT2); '... one of the objectives is socialisation and active and collaborative learning.' (HS3); '... to socialise children so they are all in contact, so they learn to relate to each other.' (T3)

And, secondly, the methodologies the teachers use in their classrooms, although they find it more difficult to put this into practice.

'We try to improve our methodologies, but it's not easy because teachers change and because of the number of children we have.' (HT2); 'so coordination in these methodological aspects isn't very good...to be honest with you.' (T3)

However, we must explicitly mention the responses given by school 4 as they highlight disagreements on the existence of a joint education plan.

'... there are common lines of action, but then they're not followed ...

There's not a line of action in teaching ... Teachers do not operate at a CRA level.' (HS4)

However, establishing some shared courses of action is not enough and, in this respect, the management teams emphasise the importance of conveying enthusiasm 
and the need to work as a team and for them to be the first to lead by example and to get involved. They point out that the teaching staff usually responds satisfactorily to the course of action and that they try to do their best and quickly 'join the group'. Consequently, the CRA shares common requirements and commitments for the success of joint education plans: everyone needs to be involved.

'I think that, as we are a small school and there are so few of us, we all have to get involved in everything because, otherwise, it would be impossible to keep going ... If one person doesn't do it, then that's something that stops working at the school.' (HT2.2); 'There are some things that we have to do. We all have to do it as the management team is also teaching staff.' (HS1)

'You encourage the teaching staff to move, but you have to move first if you want them to follow, you set an example, don't you? ... you ask the same of yourself as you ask of others.' (HS3); '... I understand that if I ask that of myself, I can ask it from the rest of the group as well.' (HS1); 'The demands made are the same for everyone.' (T2); '... if the one asking us to work hard doesn't work hard themselves.' (T1)

More bureaucratic tasks, such as the review and/or preparation of education plans (School Education Plan, Internal Regulations, School Community Plan, Innovation, and so on), are distributed by the management team among everyone so every person is responsible for their part. A work schedule is always established for these tasks and for preparing other activities, and they aim to meet the deadlines, although they say there is some flexibility.

'Some work is distributed, such as preparing education plans and other things. They're divided up and everyone is given some tasks to do for which they are responsible ... Deadlines are set, which are the same for everyone, but there's flexibility. Because, if this is not established or not established well, it's a disaster.' (HT2.2); 'As far as work is concerned, if school 
documents have to be reviewed or prepared, this is done in groups and everyone plays a role.' (T2)

\section{Subcategory 2 Continuing professional development and training}

The perception that members of the management teams have is that they always try to encourage, foster and promote the training of CRA teaching staff. They prioritise new content that boosts innovation and that is always based on the school's needs. The teachers also perceive these ideas.

'... they try to promote training and be up-to-date with the latest.' (HT2.2);

'... we try to have the best training at the school.' (HT3); '... we have training hours at the school ... they give us information ... ask ... suggest.' (T3); '... training that helps us with our immediate work ... Based on the needs observed at the school.' (HT2.1); '... I think the training they do is more based on the education plan than chosen by the CRA.' (HS1); '.. the initiative is based on analysing requirements at the school.' (T1)

By prioritising the school's needs above individual training needs that the teaching staff may have, the design of the training is dictated by the previous year, despite the fact that most of the staff is usually new every year. Nevertheless, although the training design is based on the CRA plan, they emphasise that it is open to debate and, therefore, flexible. Although the training is based on the school education plan, teachers appreciate that they are asked to suggest changes or for their opinion. Both the headteacher's ability to decide and teamwork play an important role in this point.

'... via the teaching teams.' (HS1); '... the work teams are continuous.' (HS3)

Both the management teams and the teachers stress that they are involved in one of the practical and functional current training forms: CRA training taken to the classroom. Concerning training topics, they highlight methodology, especially the most appropriate methodology to ensure pupils are competent. Nevertheless, on this point, there are also discrepancies at school 4. 
'It doesn't matter whether the teaching staff receives more training ... this person is only temporary.' (HS4)

The interviewed teachers have the perception that the management teams place importance on training and opinions on this matter appear to agree. The teaching staff feels that they actively participate in decisions on CRA training.

'... I do notice the headteacher's influence on our training ... Based on results, suggestions ...' (T1); '... they ask us, they consult us ...' (T3)

Management team members emphasise the work the COFO (training coordinator) performs, at least referring to the dissemination of training by the CIFE (Centre of Initiatives for Training and Employment) and, in this line, individual training may or may not be related to the school's training.

'Regarding training outside the school, everyone signs up and does largely what they wish.' (HS1)

Sometimes, the responses show us some difficulties in understanding the purpose of professional development, although, in most cases, it is linked to teamwork and innovation processes. In both cases, some of the basic ideas are, firstly, the need to invest time and, secondly, having no time for coordination.

'... it's really hard, because innovating requires work, a lot of time, preparation, searching. I think it's hard because you have your hours, but then people leave here and want to get on with their life.' (HT2.2) 'We can only coordinate on Wednesdays, which is when we have the CRA meeting.' (HS3)

We found different ideas on the CRA's specificity, since it was emphasised that, as CRAs are small, it is easier to know what is happening in the classroom so teaching can be improved, although each locality also has its own requirements. 
'... as we are a small group of colleagues ... we are a little bit more involved with each other.' (T2); 'This is a very particular school and ... we have to take advantage of what we can.' (HT2.1); '... despite being a CRA, requirements differ greatly from one town to another.' (T3)

However, there is also the idea that large schools in a single space make coordinated work more possible.

'... we saw each other every day and could make the most of that to do more things together.' (HS1)

\section{Subcategory 3 Collaborative organisation}

The importance of collaboration among management team members and between them and the other teaching staff was highlighted as a priority and, in general, they consider that there is an organisation at their schools that promotes collaboration and participation and that is closely linked to the headteacher's ability to create an atmosphere of involvement and, therefore, sometimes the headteachers capacity for initiative was felt to be missing.

'When decisions have to be made, they are usually made by everyone.' (HS4); 'We all form part of the education plan and it's successful because of everyone's contributions. New people see the situation, they see the atmosphere of collaboration, everything that we do together, that we're all a team and then, I think, the headteacher should do something; she does, but I think she doesn't have to do much, because we all help to convey the information ... we're all a team here.' (HS3)

'Not in an organised fashion ... on occasion yes ... she offers help, but she doesn't take the initiative.' (HS4)

The consequence of fewer teachers, although separated physically, is that most of them take part in coordinating certain tasks and/or plans, so that everyone can play 
a prominent role. Nevertheless, everyone we interviewed said that, although the organisational structure and management promote collaboration, not everyone becomes involved to the same extent. This is mainly due to the temporary status of some teachers and also regulations that do not consider the specific nature of rural schools.

\footnotetext{
'We all immediately have our tasks here.' (HT2.2); '... that each of us coordinates a programme or something. Everyone feels important on the teaching staff.' (HT2.1) 'The level of involvement is good at my school ... we've always worked as a team because that's the only way to make progress.' (HT3); 'We work a lot together in groups.' (T2); 'They do try to do things together.' (T3)
}

'Then it depends on the year; the teachers get more or less involved, some people can't really be bothered.' (HS1); 'The teaching staff changes every year. Half the teaching staff changes, so you have to try to get one half involved in the dynamics that the other half already knows ... Then the legislator doesn't think about rural schools.' (HT3)' '... the government should make it easier.' (HS3)

\section{Subcategory 4 Institutional improvement}

The general opinion of the interviewees is that headteachers are concerned with improving teaching and learning processes, school organisation and its culture. Their end objective is to increase the quality of the school and the teachers by following through on suggestions for innovation and improvement made by both management and teaching teams. 
'... they do try to innovate ... some proposals are put forward by management and others by teachers, who are sensitive to certain demands, and others have been suggested based on results, weak points.' (T1)

Relationships built through communication with other stakeholders forming the education community have a direct impact on proposals for change and improvement. However, not all families have a high level of participation and involvement, perhaps because the very characteristics of these localities and the cultural and economic level are a determining factor in some schools. The link between school and family is closely related to the objective of socialisation present in rural schools and to the need to rely on the environment as an educational resource.

'Another variable it can facilitate is that parents are immediately prepared to collaborate ... the parents organise themselves, in the towns and between them they bring the kids to all get together.' (HS3); 'When we do group activities, the parents volunteer to prepare a resource ... the parents have also asked to get together to do an activity.' (T3); 'We have one weekly hour of promotion of reading as part of the school's decision-making ability and once a month we invite people to come and tell us a story.' (HT2.1); 'All the families are Moroccan, so they don't have a lot of resources to help the children.' (HT2.1)

Nevertheless, sometimes the management teams feel that the families can hinder their educational and organisational work because the school and the community are closer together in the rural environment and also because some parents do not value the school. This means involvement differs even at the same CRA.

'Families complicate our tasks a bit ... sometimes they make it difficult for us.' (HT2.1); 'In the rural environment, families sometimes meddle in the school too much.' (T1); 'There are also parents who think the school is for 
childminding.' (HT3); 'Sometimes we come across families that don't value it.' (HS3); 'In some towns, there isn't that atmosphere of educational community work.' (HT3)

\section{Discussion and interpretation of the results}

School leadership is one of the cornerstones for educational improvement (Bolívar, 2012; Murillo and Hernández-Castilla, 2014). Its development needs to be studied in contexts that we could term differential due to their geographical, socioeconomic and/or cultural characteristics. Rural schools fall into one of those contexts, one that we could call 'challenging' (Domingo et al., 2016).

Although our study has its limitations due to circumstances arising during implementation, since we had to adapt the timeframe and sample characteristics to the funding we were given and to the logistic possibilities to access different rural environments, we can intuit a view of leadership that is linked to the headteachers and their ability to lead, but gives priority to the view of the team, which needs to work together and establish common guidelines after analysing the complex reality of the rural school. This is also mentioned in other studies (Ritacco and Amores, 2017). Consequently, we can say that this is educational and transformational leadership in which all members' interaction is vital and typical of the educational leadership that Hopkins (2001) considers essential for schools to be successful in challenging contexts such as rural areas. Nevertheless, the study highlights differences in the management teams' level of involvement when they are appointed rather than elected.

The interviewees pointed out that not all teachers have the right profile to be a headteacher, as the latter should be hired for certain personal characteristics and skills developed through specific managerial training (Teixido, 2008). This training should also be contextualised and moulded to the requirements of current headteachers (Teixido, 2016), since, as mentioned in the study, managing a CRA is not the same as managing a complete urban school; the former is far more complex and, above all, different. 
Nevertheless, according to the interviewees and other studies (Mallada, 2012; CEIP Ramón y Cajal, Alpartir, 2014), the current management model in Spain does not consider these particular features.

Concerning a good headteacher's personal and interpersonal skills, studied by Bolívar (2011), among others, we have found some that were already mentioned in other studies (Teixido, 2016), such as empathy (approachable, ability to listen and to dialogue...), flexibility, involvement and commitment (by example), knowledge of the educational situation, which is essential in rural schools. From this standpoint, the results highlight the importance of being able to blend personal and material resources to reach the objectives set.

The need for management to set clear organisational and educational objectives is a constant. We noted that the entire educational community needs to participate in the design of objectives, although high teaching staff turnover means there have to be some basic outlines defining a CRA and that require a clear feeling of belonging. Proposed education plans could be institutionalised, taking the school's actual needs as a starting point, and improvement in educational practice as a target, through what has been termed ethical leadership, understood as coherence between advocated values and everyday behaviour (Teixido, 2016). If the school is experienced as a community, teachers share leadership and decision-making (Bolívar, 2011), and this seems to be the desire of all the participants in this study, despite obstacles standing in their way. This would mean that the educational community's general interests would take precedence over an individual's (CEIP Ramón y Cajal Alpartir, 2014).

Along the same lines as other studies highlighting that leadership should develop teachers' skills (Elmore, 2010) and promote professional development opportunities (Timperley, 2008), one of the standout aspects of our study is appreciation for the role management plays in teaching staff's training and professional development, although we have found some problems in differentiating between the two concepts. The results emphasise the need to link training to improving practice in both the classroom and the centre, and, in that respect, views are positive. However, we have not found many 
references to the specific role rural teachers play as integrators-links and sociocultural coordinators (Morales, 2006). Professional development is understood as linked to teamwork and, in this case, the view is that there are more challenges than possibilities, since teachers fail to take full advantage of ICT networking opportunities often due to lack of interest. Furthermore, as part of the teaching staff is temporary, there is no need for them to do extra work on aspects they are minimally concerned with (especially aspects linked to specific CRA model subjects). This explains why individual training is mostly not linked to issues related to rural schools.

Consequently, we should refer to the relationship the interviewees, mostly management team members, establish between all educational leadership elements and school improvements, in other words, improving learning and student socialisation processes, which require making the most of teaching staff's positive attributes and involving the community (families and the local community).

The specific nature of rural schools and CRAs - the predominant model in the Spanish education system-requires a different educational leadership that understands and assumes its possibilities and strengths to make up for its weaknesses and threats, supported by a shared commitment with the entire community and linked to teaching and learning processes. Therefore, more research is needed on the subject to propose specific training for educational leadership in management that can adapt to the real requirements of schools in rural contexts. 


\section{References}

Álvarez, M (2010). Liderazgo compartido: buenas prácticas de dirección escolar. España: Wolters Kluwer Educación.

Barthes, A y Alpe, Y. (2017). The rural school, a polysemous object with significant societal challenges? Current research contexts and positions, In Educational policies and territorial inequalities, 5-14.

Bernat, A (2009). Escuela rural e ideologías. Jornadas sobre Educación en el Medio Rural. Teruel: Gobierno de Aragón-Universidad de Zaragoza.

Boix, R. (2003). Escuela rural y territorio: entre la desruralización y la cultura local. Revista Digital eRural, Educación, cultura y desarrollo rural, 1, 1-8.

Boix, R. (2014). La escuela rural en la dimensión territorial. Innovación Educativa, 24,89-97. http://dx.doi.org/10.15304/ie.24.1959

Bolívar, A. (2011). Aprender a liderar líderes. Competencias para un liderazgo directivo que promueva el liderazgo docente. Educar, 47 (2), 252-275.

Bolívar, A. (2012). Políticas actuales de mejora y liderazgo educativo. Málaga:

Aljibe.

Bustos, A (2009). La escuela rural española ante un contexto en transformación Revista de Educación, 350. Septiembre-diciembre 2009, pp. 449-461.

Canário, R (2008). Escola rural: de objeto social a objeto de estudio. Santa María, 33(1), 33-44.

CEIP “Ramón y Cajal”-Alpartir (2014). Liderazgo, gestión y dirección escolar en la escuela rural. Fórum Aragón, 11, 21-24.

Chapman, J. D. (2005). Recruitment, retention, and development of school principals. Lenders: International Institute for Educational Planning. 
Corchón, E.; Raso, F. y Hinojo, M. a A. (2013). Análisis histórico-legislativo de la organización de la escuela rural española en el periodo 1857-2012. Enseñanza \& Teaching, 31, 147-179.

Day, C., Gu, Q., \& Sammons, P. (2016). The impact of leadership on student outcomes: How successful school leaders use transformational and instructional strategies to make a difference. Educational Administration Quarterly, 52(2), 221-258.

Domingo, J. (coord.) (2016). Liderazgo eficaz en contextos desafiantes, en Globalización y organizaciones educativas, pp. 104-126. XIV Congreso Interuniversitario de organización e Instituciones Educativas. Zaragoza: Universidad de Zaragoza.

Elmore, R. F. (2010). Mejorando la escuela desde la sala de clases. Santiago de Chile: Fundación Chile

Gallardo, M. (2011). La escuela de contexto rural: ¿de la diferencia a la desigualdad? Revista Iberoamericana de Educación, 55 (5), 1-10.

García, F.J, Pozuelos, F.J y Álvarez, C. (2017). Uso de los libros de texto en la educación rural en España. Sinéctica, 49. https://sinectica.iteso.mx/index.php/SINECTICA/article/view/707

Gauthier, P.-L. \& Luginbühl, O. (2012). L'éducation en milieu rural : perceptions et réalités ", Revue internationale d'éducation de Sèvres, 59.

Gómez, C. (2007). Lo rural en los planes educativos el Gobierno de Aragón. Revista de Desarrollo Rural y Cooperativismo Agrario, 10, 83-104.

Gunter, H. M. (2006). Educational leadership and the challenge of diversity. Educational Management Administration \& Leadership, 34 (2), 257-268.

Harris, A. y Muijs, D. (2003). Teacher leadership: principles and practices. Nottingham: National College for School Leadership. 
Harris, A. y Chapman, C. (2002). Leadership in schools facing challenging circumstances. Management in Education, 16(1), 10-13.

Hopkins, D. (2001). Instructional leadership and school improvement. Effective leadership for school improvement, 55-71.

León, M.J, Crisol, E y Moreno, R (2018). Las tareas del líder inclusive en centros educativos de zonas desfavorecidas y favorecidas. REICE, Revista Iberoamericana sobre Calidad, Eficacia y Cambio en Educación, 16(2), 21-40. https://doi.org/10.15366/reice2018.16.2.002.

Mallada, L.M. (2012). La dirección de un Centro Rural Agrupado. Revista del Fórum Europeo de Administración de la Educación: Organización y gestión educativa, $6(20), 8-12$.

Maureira, Ó., Gara, S. y López, P. (2015). Reconfigurando el sentido del liderazgo en organizaciones escolares contemporáneas: La perspectiva del liderazgo distribuido. Revista Complutense de Educación, 27 (2), 689-706.

Morales, N. (2006). Padres y profesores, dos importantes agentes sociales en las organizaciones escolares españolas y sus interrelaciones en un contexto local. Convergencia, 13 (41), 87-116.

Morales, N. (2007). Escuela, medio rural e igualdad de oportunidades ¿un trío imposible? Documentación Social, 146, 135-154.

Morales, N. (2017) The Spanish rural school from the new rural paradigm. Evolution and challenges for the future. Revista Colombiana de Ciencias Sociales, 8(2). http://www.funlam.edu.co/revistas/index.php/RCCS/article/view/2090

Muijs, D. (2007). Teacher leadership in (In) action three case studies of contrasting schools. Educational management administration \& leadership, 35(1), 111134. 
Mullis, I., Martin, M., Ruddock, G., O'Sullivan, Ch. y Preuschoff, C (2009). TIMSS 2011 assessment frameworks. Boston: International Association for the Evaluation of Educational Achievement; International Study Center.

Murillo, F. J. (2006). Dirección escolar para el cambio: Del liderazgo transformacional al liderazgo distribuido. REICE. Revista Electrónica Iberoamericana sobre calidad, eficacia y cambio en educación, 4(4), 11-24.

Murillo, F y Hernández-Castilla, R (2014). Liderando escuelas justas para la justicia social. Revista Internacional de Educación para la Justicia Social (RIEJS), 3(2), $13-32$.

Prats, J (coord.) (2004). Las Ciencias Sociales en España. Historia inmediata, crítica y perspectivas. Vol. 2, Antropología y Etnología. Madrid: Editorial Complutense.

Ritacco, M y Amores, J (2017). Dirección escolar y liderazgo pedagógico: un análisis de contenido del discurso de los directores de centros educativos en la Comunidad Autónoma de Andalucía (España). Educaçao e Pesquisa, 5 octubre http://www.scielo.br/scielo.php?pid=S151797022017005011102\&script=sci $\underline{\text { arttext }}$

Sanz, M. A. (2009). Educación y territorio. Encrucijadas socioculturales. Jornadas sobre Educación en el Medio Rural: encrucijadas y respuesta. Teruel: Gobierno de Aragón-Universidad de Zaragoza.

Spillane, J. y Camburn, E. (2006). The practice of leading and managing: the distribution of responsibility for leadership and management in the schoolhouse. American Educational Research Association, 22, 1-38.

Tapia, L. y Castro, P. (2014). Experiencia educativa, educar desde un CRA. Tendencias Pedagógicas, 24, 415-428.

Teixidó, J (2008). Competencias para el ejercicio de la dirección escolar. Bases para un modelo de desarrollo profesional de directivos, en Fernández, R y García, J 
(coord.). Competencias profesionales para la dirección de los centros educativos. Albacete: FEAEC Castilla -La Mancha.

Teixidó, J (2016). Formación para la dirección escolar: el ¿qué? y el ¿cómo? Visión de los profesionales. en Globalización y organizaciones educativas, pp. 32-37. XIV Congreso Interuniversitario de organización e Instituciones Educativas. Zaragoza: Universidad de Zaragoza.

Timperley, H. (2008). Teacher professional learning and development. París: UNESCO, International Academy of Education \& International Bureau of Education (Educational Practice Series; 18)

Wertz, F., Charmaz, K., McMullen, L., Josselson, R., Anderson, R. y McSpadden, E. (2011). Five ways of doing qualitative analysis. Londres-Nueva York: The Guilford Press. 